\title{
Contrastive Analysis of Indonesian and Javanese Languages and Its Prospective Implication for Language Learning
}

\author{
Roni Sulistiyono \\ Indonesian Education Department \\ Ahmad Dahlan University \\ Yogyakarta, Indonesia \\ roni.sulistiyono@pbsi.uad.ac.id \\ Pujiati Suyata \\ Indonesian Education Department \\ Ahmad Dahlan University \\ Yogyakarta, Indonesia \\ pujiati.suyata@mp.uad.ac.id
}

\author{
Triwati Rahayu \\ Indonesian Education Department \\ Ahmad Dahlan University \\ Yogyakarta, Indonesia \\ triwaturahayu@ymail.com
}

\begin{abstract}
This study was aimed at analyzing contractive comparisons between Indonesian language and Javanese one. Both languages are belong to the Western Malay Polynesian group, but then have developed under varieties of influences and have experienced differences in some respects. The contrasts between both languages could provide contributions for students whose Javanese and Indonesian learner as their L1 and L2 respectively. For gaining the data of contradictions between Indonesian and Javanese, a survey using contrastive language comparison method was done. The instrument was using network system which contains 500 vocabularies. The data were in the form of descriptive qualitative. The results indicated some contrasts between Indonesia and the Javanese languages. The result of this study is feasible to be used as Indonesian teaching materials based on Javanese language.
\end{abstract}

Keywords-contrastive comparison, Indonesian and Javanese language, language teaching

\section{INTRODUCTION}

History reveals that Indonesian language is derived from the Malay language which in 1928 was inaugurated as Indonesian language[1][2]. In its development, Indonesian obtains diverse influences, both from the regional languages and foreign languages, such as Dutch and English. In the last decade, the rapid development of science and technology, and English language influence the development of Indonesian language.

In terms of kinship, Indonesian (Malay) is a relative of Javanese language, namely Western Malay Polynesia. The studies on West Polynesia Malay related to the subgrouping have been conducted. The Malay language subgroups are Malay, Sundanese and Javanese[3]
Currently, the Javanese language is used by a number of speakers in the province of Yogyakarta, Central Java, and East Java in everyday life. In addition, the Javanese language is also used in traditional official ceremonies, such as wedding ceremonies, 7 months of pregnancy, and birth ceremony. Javanese language is also taught in schools. For elementary level, Javanese language becomes their L1.

Indonesian has been established as the language of instruction in schools [4] (the Education Act No. 20 year 2003)Thus, the language becomes the language of instruction at all levels of education, including primary school level. This poses a problem for elementary school students since their L1 is Javanese language. They have to learn twice, first to learn Indonesian language as the language of instruction; secondly they also have to learn Indonesian language learning materials. In fact, in Curriculum 2013, which focus on thematic integrative, Bahasa as a means of communication in other subjects teaching and learning process. Therefore, Indonesian literacy becomes the important one.

The study of contrastive comparison between Javanese and Indonesia can bridge these difficulties. The beginner can use the contrast that occur in both languages and use Indonesian language as the language of instruction and as a subject. Similar conditions occurred in Kenya, when Margaret conducted a study on improving reading competence for elementary school student[4].

Indonesia has a national language namely Indonesian language, many local languages and also dialects. In accordance with the Constitution-1945, Indonesian language becomes the national language, the state language, and Indonesian united language. Moreover, Indonesian language has also been designated as the language of education (Law on National Education System No. 20 year 2003). Indonesian has 
been set as the language of instruction at all levels of educatio[5]. Therefore, the Indonesian language needs to be mastered by the students. The disruption of language acquisition will be disrupted the absorption of other subjects in school[6]

Beside Indonesian, in Indonesia are found local languages or dialects. The numbers of those languages observed in 2011 are around 746. Local languages used by the people in their everyday life. Their children also use the local language as their first language, especially in rural areas. One of some studies of the child's L1, in Yogyakarta, stated that the L1 of the urban child is Indonesian, while L1 of the suburb children are Indonesian and Javanese, for rural areas, the Javanese language is their L1. This fact also occurs in other areas. This is well documented in the literature[2].

In terms of history, Indonesian derived from Malay language. According to the characteristics of the language, the language is included in a group of Malay Polynesian (MP). Other languages in Indonesia are categorized as west MP group and East MP group[7]. The languages which are included in West MP namely Malay, Sundanese, Javanese, Madura and Bali. Timor, Sumbawa, Sumba, Maluku and Papua languages are categorized as west MP. The difference among the local language and Indonesian language create the difficulties on the Indonesian language mastery by the elementary school students[3]

\section{THEORETICAL REVIEW}

\section{A. Linguistic Characteristics of Indonesian and Javanese}

The characteristics of both language, it appears that although Indonesian and Javanese are from 1 same subgroup, there are some differences indicated[3]. The comparative linguistics study has been observed this phenomenon. Polynesia Malay Language are divided into two subgroup namely Western Polynesia Malay Language and East Polynesia Malay Language. The Western Polynesia Malaylanguage includes Sumatra, Javanese, Balinese, and Lombok languages. In addition, East Polynesia Malay-language which have different characteristics with Western Polynesia is divided into two other subgroup, namely Central Polynesia and East Polynesia. Maluku and Papua languages are the example of East Polynesia Languages[3].

Based on Article 36 Section XV "The State's Flag, Language, and Coat of Arms, and The National Anthem" of The 1945 Constitution of the Republic of Indonesia, Bahasa Indonesia has been established as the state language of Indonesia It is also established as the language of unity, the national language, and the language of state administration. Moreover the Indonesian language has also been designated as the language of instruction in schools at all levels of education, according to the National Education Act Article 33, paragraph 2 number 20 in 2003. These requirements have an impact on the need for the Indonesian language mastery by the students on all levels of education.

Beside the Indonesian language as the national language, Indonesia also has hundreds of local languages or dialects.
Data in 2011 showed that the numbers of local languages are about 746. There is also an indication of reduction of the local languages numbers. This happens because of the effect of the development of science and technology. Therefore, the local language are protected by law since the local language is the entrance of ethnic culture, local knowledge, and traditional noble values.

In education, local languages are also protected by the law, the National Education Act No. 20 of 2003 states that for areas that are still difficult to use Indonesian as a language of instruction, they are allowed to use the local language. Thus, the teacher may explain the subject matter by using local language. However, it took the impact of the slow absorption of subjects by students. The time required is also much longer than if the teacher explained using Indonesian language directly. In order to give the solution, the use of the local language is used in teaching and learning proses.

\section{B. Indonesian and Javanese Contrastive Analysis}

Contrastive analysis is part of the Comparative Linguistics Science. In Comparative Linguistics, Contrastive Linguistics is a section which studies the comparison between languages within the same period. In addition, a comparative study of different languages time is called Comparative Historical Linguistics. During its development, the theories of Contrastive Linguistics are used for teaching learning matter, especially for second or foreign language learning. Indonesian is a second language for speakers whose L1 is Javanese language. The basic Contrastive Linguistics theory then is able to be used for Indonesian teaching learning process.

Although Indonesian and Javanese are in one subgroup, namely Malay Polynesian, there are similarities and differences between both languages[8]. Contrastive analysis of both languages discovers that in terms of phonology, for example, the phoneme /a/ in the second syllable of Indonesian words change into /e/ in the Javanese language e.g. /santan/ in Indonesia turns into /santen/ in Javanese. While /pagar/ turns into /pager/, /mantap/ turns into /mantep/, / atap/ turns into latep/, or /kesal/ turns into /kesel/.

At the level of the sentence, it could be seen from the following examples. The phrase "Iki dolanane sapa?" In the Javanese language, can be "Ini mainannya siapa?" in Indonesian. In fact, in a good Indonesian systematic language, it would be "Ini mainan siapa?" The contrast between the two languages that can be the basis of Indonesian language for students whose L1 is Javanese language.

\section{Reading Learning Strategy}

One of the learning to read theory, namely bottom up theory[9]. This model believe that reading comprehension starts from the smallest language elements, namely phonemes and words then sentences, up to the overall understanding of the text. This model seems appropriate for L2 students in learning Indonesian language. With contrastive analysis theory, they learn to recognize the difference phonemes, words and sentence structure of first and second language. Furthermore, it can be done overall understanding of the text. 
Another strategy is the top-down models[10]. In this model, the text is understood by using information that is already owned by the readers. In analyzing something, reader has to develop meaning and not to understand the meaning of words. The process of top-down strategy is to predict, to guess contextually, to image association, and to find certain clues. Based on these descriptions, it appears that this model is appropriate for the advance learners but not for the beginners. The advance learners are required to understand the whole meaning, both literary and inferential meaning.

\section{METHOD}

This study began with a literature review on the theories of language contractive comparison, followed by a survey related to the identification of contrasts between Indonesian and Javanese language. The instrument used was "network system" that contains 500 vocabularies of Indonesian words and the Javanese translation. The samples were 27 people, consisting of both men and women, aged 40-60 years who lives in the same area for two generations (both parents and childrens live in the same area). They were graduated from primary and junior high school level. They are agricultural work, self-employed, or housewife. All of them have complete speech synthesizers, and rarely travels to outside the area. The data were in the form of descriptive qualitative. The study was located in Bantul, Sleman and Gunung Kidul districts, Yogyakarta.

\section{FINDINGS AND DISCUSSION}

\section{A. Findings}

Based on the analysis, some contrasts between the Indonesian and Javanese language were found. The contrasts between both languages are described as follows.

First, the phoneme /a/ in the second syllable of Indonesian word turns into /e/ in Javanese language. It can be seen from the word "pagar" turns into "pager" in Javanese. Another examples are "santen" turns into "santen", "atap" to "atep", "pagar" to "pager", "asap" to "asep", "sambal" to "sambel", and "arang" to"areng". The examples of phoneme contrast /a/ into /e/ in Javanese are numerous. The modification is regular e.g. "deras" (Indonesian) into "deres" (Javanese), "matang" (I) into "mateng"(J), "cepat" (I) into "cepet" (J), and "hangat" into "anget".

Second, the phoneme h- at the beginning of the words into (zero) in Javanese.From the analysis, there is regular sound reflex from Indonesian into Javanese namely phoneme $/ \mathrm{h} /$ at the beginning of the word into $/ O /$ zero in Javanese e.g. "hidung"(I) into "irung" (J), "hati" into "ati", "hujan" (I) into "udan" (J), "hangat" (I) into "anget"(J), "hutang" (I) and "halus" (I) turn into "utang" and "alus" (J).

Third, the phoneme $/ \mathrm{b} /$ in Indonesia turns into $/ \mathrm{w} /$ or remain /b/ in Javanese e.g. "bulu" (I) into "wulu" (J), "bungkus" (I) into "wungkus" (J), "beras" (I) into "wos" (J), "cobek" (I) into "cowek" (J), "bulan" (I) into "wulan" (J), "abu" (I) into " awu" (J), "batu" (I) into "watu" (J), "balas" (I) into "wales" (J), "balik" (I) into "walik" (J), "basuh" (I) into "wasuh" (J). Beside /b/ (I) changes into /w/ (J), /b/ (I) can also be bias example "bulan"(I) remain as "bulan"(I) or turn into "wulan" (J)

Fourth. the phoneme /ai/ in Indonesian turns into /e/ in Javanese e.g. "gadai"(I) into "gade"(J), "kedelai"(I) into "dele"(J), "serai" (I) into "sere"(J), "balai"(I) into "bale"(J), and gulai" (I) into"gule"(J).

Fifth, the phoneme /au/ in Indonesian turns into /o/ in Javanese e.g., "hijau" into "ijo", "pisau" into "peso", "danau" into "dano", "jauh" into "doh", and "kerbau" into "kebo".

Sixth, the phoneme /e/ in the first syllable turns into $\mathrm{O}$ (zero) in Javanese e.g. "ketela" (I) into "tela"(J), "kecambah" (I) into "cambah"(J), "selasih"(I) into"tlasih" (J), "kerudung" (I) into"kudung"(J), "keranjang"(I) menjadi "kranjang"(J), “kerupuk"(I)into"krupuk"(J),"kedondong”(I)into

"dondong"(J).

Seventh, Indonesian and Javanese language as part of Western Austronesian Languages follow The RGH Law e.g. "kapur" (I) into "apu" (J); "ratus"(I) into "atus"(J), "rusuk", (I) into "usuk"(J), “turut"(I) into “tut"(J)

Eighth, Indonesian and Javanese as part of Malay Polynesian follow RDL Law e.g. "empedu" (I) into "peru"(J), "padi" (I) into "pari"(J), "tidur"(I) into "turu"(J), and "udang"(I) into "urang" (J).

\section{B. Discussions}

Indonesian and Javanese are as group of languages namely Western Malay Polynesian (WMP). However, among the similarities, it can be found that some differences also occur between the two languages. The contrast can be used by teachers in teaching Indonesian language, especially for the beginner whose mother tongue L1 is Javanese language.

By following these contrasts that exist in both languages,L1 and L2, the learners are easily learn L2, which in this case Indonesian. This is in accordance with the purpose of studying Comparative Linguistics Contrastive that one of them is learning the language. The phonological contrasts in both languages occur regularly and it becomes useful for language learning.

This study is at the level of phonemes. However, the actual study can be developed into the other levels like the word, group of words, or sentences. There is a contrast between Javanese and Indonesian sentences. For example, in Javanese a sentence: Iki bukune sapa? People often translate it into "Ini bukunya siapa?" The element of "nya" in the Indonesian language is wrong, because it is the Javanese language constructs.

In teaching practice, teachers can teach the contrast by using appropriate instructional media, such as computer-aided media. Media should be created as practice, interesting, and fun learning aids. Make sure to use interesting images, colors, and sounds to encourage the students to learn. 


\section{CONCLUSION}

The conclusion of this study are: first, Indonesian and Javanese are in one group of languages, namely Western Malay Polynesia. Many similarities are found between the two languages, but there are also differences. Second, contrasts that exist between the two languages include several things, which in this case, is at the level of phonemes. Third, the contrast occurs in phoneme /a/ in the second syllable turns into /e/ weak in Javanese, Phoneme h- at the beginning of the syllable turns into 0 (zero) in Javanese, Another regular contrast occurs in some phonemes, namely /ai/ turns into /e/, /ai/ into /e/, /au/ into /o/, /e/ into 0 (zero). Indonesian and Javanese language as part of the Western Austronesian language family follow the RGH Law, while Indonesian and Javanese as Western Malay Polynesian follow the RDL Law. Fourth, the contrast between the two languages can be used by the L1 Javanese students for learning Bahasa.

\section{REFERENCES}

[1] Darmiyati Zuchdi. "Bahasa dan Sastra Indonesia sebagai wahana pendidikan karaktr" dalam Pendidikan Karakter dalam Perspektif Teori dan Praktik. Yogyakarta: UNY Press; 2011.

[2] Pujiati Suyata, Triwati Rahayu, Roni Sulistyana. Analisis Literasi Bahasa Indonesia Peserta Didik SD Kelas Permulaan yang Berbahasa Ibu Bahasa Daerah. Proceeding Seminar Internasional Riksa Bahasa X "Literasi dan Budaya Bangsa". Bandung. 2016: 227-238.

[3] Pujiati Suyata "Studi bahasa dan budaya Austronesia di Indonesia dalam perspektif integritas bangsa".dalam Kearifan Sang Profesor. Yogyakarta: UNY Press; 2007.

[4] Margaret M. Dubeck, Matthew C. H. Jukes, George Okello. Early Primary Literacy Instruction in Kenya.Comparative Education Review. 2012; 56(1): 48-68.

[5] Triwati Rahayu, et.al. Mahir berbahasa Indonesia. Yogyakarta: PBSI Univ. Ahmad Dahlan; 2016.

[6] Ari Kusmiatun. Improvement of reading comprehension and rhetoric speaking skills of elementary school students through mind-mapping strategies. Jurnal of education, research in theory and practice of education. 2008; 1(1): 1-8.

[7] Suhardi, Pujiati Suyata."Analisis kontrastif bahasa Indonesia dan daerah dan Implikasinya dalam pembelajaran bahasa kedua: Model multikulturalisme dalam pembelajaran bahasa". Penelitian. Direktorat Jenderal Pendidikan Tinggi; 2009.

[8] Suhardi, Joko Santosa. Analisis kontrastif bahasa Indonesia, Lio, dan Banjar. Litera: Jurnal Penelitian Bahasa, Sastra, dan Pengajarannya. 2011; 10 (2):159-170

[9] Vivi Kusuma Ardhani Keefektifan pembelajaran dengan pendekatan bottom-up dan top-down dalam pemahaman membaca teks bahasa inggris siswa kelas VIII SMP N 3 Yogyakarta (Thesis). Yogyakarta State University; 2012.

[10] Ari Kusmiatun. Improvement of reading comprehension and rhetoric speaking skills of elementary school students through mind-mapping strategies. Jurnal of education, research in theory and practice of education. 2008; 1(1): 1-8. 